\title{
Det kongelige Bibliotek og de humaniorastuderende
}

af undervisningsleder, cand.mag. Niels Ole Pors, Danmarks Biblioteksskole

\section{Indledning}

Den følgende artikel indeholder analyser af studenterbrugerne ved Det kongelige Biblioteks tre afdelinger. Artiklen baserer sig på den undersøgelse, der blev foretaget i efteråret $1994 \mathrm{og}$ publiceret i $1995 .^{\circ}$ Artiklen kan betragtes som et supplement til den publicerede undersøgelse, idet der foretages mere specificerede analyser. I artiklen behandles blot 6 grupper af humanistiske studerende. Analyserne i artiklen omhandler primært to forhold. Det drejer sig om brugernes anvendelse af edb-søgninger og succes med hensyn til at få den litteratur, de kommer efter. Begge disse emner ses også i forhold til de studerendes subjektive opfattelse af, hvorledes udbyttet af dagens biblioteksbesøg har været. Analyserne foretages også i forhold til de tre betjeningssteder.

\section{Udbytte af dagens biblioteksbesøg}

Af tabel 1 fremgår det, at der er høj grad af tilfredshed med udbyttet af dagens biblioteksbesøg. Der er ingen statistisk signifikant forskel på tilfredsheden med udbyttet ved de tre betjeningssteder, selvom der dog synes at være en svag tendens til, at Slotsholmen vurderes som en anelse bedre i så henseende. Tabel 1 indeholder oplysninger om alle personer i de 3 brugergrupper, og ikke kun studerende fra de 6 udvalgte fag.

Tabel I: Sammenhæng mellem betjeningssted og tilfredshed med udbyttet af dagens biblioteksbesøg; i \%.

Tilfreds

Nogenlunde

Utilfreds

Total

Amager
68
24
8
459

Slotsholmen 76

Fiolstræde Total

Chi $i$ anden $=7,6 p=0,107$ 
Det kan tænkes, at der er en sammenhæng mellem tilfredshed med udbyttet og den hyppighed, man kommer på biblioteket med. Tabel 2 indeholder oplysninger om dette forhold, og der er tale om hele brugergruppen og ikke blot de 6 udvalgte fag.

Tabel 2: Sammenhæng mellem tilfredshed med udbytte og biblioteksbenyttelseshyppighed; i \%

$\begin{array}{lcccc} & \text { Tilfreds } & \text { Nogenlunde } & \text { Utilfreds } & \text { Total } \\ \text { ugentligt } & 74 & 21 & 5 & 653 \\ \text { sjældnere } & 66 & 23 & 11 & 517 \\ \text { Total } & 823 & 260 & 87 & 1170\end{array}$

chi $i$ anden $=19,6 p=0,00005$

Det er indlysende, at der synes at være en sammenhæng mellem benyttelseshyppighed og tilfredshed med udbyttet. Jo oftere man kommer på biblioteket, des mere tilfreds tenderer man til at være med udbyttet af besøget. Tabel 2 giver sammenhængen som helhed for de tre betjeningssteder. Vi vil herefter se på, om sammenhængen genfindes på hvert af de tre betjeningssteder. Vi kan konkludere, at sammenhængen genfindes i forhold til Slotsholmen, hvor den er stærk, og i forhold til Fiolstræde, hvor den er mindre stærk, mens der ikke synes at være en tilsvarende sammenhæng ved Amagerafdelingen. Dette skal ses i sammenhæng med, at de tre brugergrupper har et noget forskelligt benyttelsesmønster vedrørende benyttelseshyppighed. Amagerafdelingens brugere benytter for næsten $70 \%$ 's vedkommende biblioteket en gang ugentligt eller ofte. De tilsvarende andele for Slotsholmen og Fiolstræde er henholdsvis $50 \%$ og $45 \%$.

\section{De humaniorastuderende}

De 6 grupper af studerende fordeler sig således på betjeningsstederne:

Tabel 3: Fordeling af de 6 studentergrupper på betjeningssteder. I absolutte tal.

hum

medier, kunst

litteratur

sprog

kultur, filosofi

historie

lalt

$\begin{array}{cccc}\text { Amager } & \text { Slotsholmen } & \text { Fiolstræde } & \text { ialt } \\ 36 & 22 & 16 & 74 \\ 40 & 17 & 13 & 70 \\ 104 & 17 & 17 & 138 \\ 91 & 20 & 13 & 124 \\ 50 & 30 & 29 & 109 \\ 55 & 46 & 19 & 120 \\ 376 & 152 & 107 & 635\end{array}$

Det fremgår, at der i dette uddrag indgăr 635 studerende. Det er godt halvdelen af brugergrupperne ved disse tre betjeningssteder. Det fremgår også, at Amager- 
afdelingen qva sin tilknytning til den humanistiske del af Københavns Universitet er godt repræsenteret i forhold til de to øvrige betjeningssteder. De 6 grupper af humaniorastuderende anvender i stor udstrækning alle tre betjeningssteder, selvom der er en klar tendens til, at studerende, der læser sprog og litteratur, i langt større udstrækning end de øvrige grupper holder sig til biblioteksafdelingen på Amager.

Tabel 4: Studentergruppernes angivelse af tilfredshed med udbyttet af dagens biblioteksbesøg; i $\%$.

\section{hum}

medier, kunst

litteratur

sprog

kultur, filosofi

historie

lalt

chi i anden $=1,3 p=0,22$

$\begin{array}{cccc}\text { tilfreds } & \text { nogenlunde } & \text { utilfreds } & \text { ialt } \\ 63 & 32 & 6 & 72 \\ 71 & 25 & 4 & 68 \\ 65 & 26 & 9 & 131 \\ 79 & 17 & 5 & 121 \\ 76 & 17 & 7 & 104 \\ 71 & 20 & 9 & 115 \\ 434 & 135 & 42 & 611\end{array}$

Det fremgår meget klart, at der ikke er forskel i opfattelsen af udbytte mellem de 6 brugergrupper. Der er forholdsvis få udsving i de andele, der angiver tilfredshed eller utilfredshed. Der er herefter undersøgt, hvorledes de 6 brugergrupper adskiller sig ved de 3 betjeningssteder, også i forhold til variablen udbytte. Det viser sig, at der på det enkelte betjeningssted ikke er forskel på de forskellige grupper studerendes angivelse af deres tilfredshed med udbyttet af dagens biblioteksbesøg. Konklusionen er naturligvis ikke, at de tre betjeningssteder i lige stor udstrækning er indrettet ens til disse 6 grupper af humaniorastuderende, men snarere at de forskellige studerende i forhold til formål ikke oplever en forskelsbehandling.

Tabel 5: Køn og tilfredshed med udbytte; i \%. Alle humaniorastuderende og litteraturstuderende

mær.d ialt

kvinder ialt

mænd - litteratur

kvinder - litteratur

\section{tilfreds}

68

73

51

70

nogenl
22
22
30
25

25 utilfreds

9

5

19

5 ialt 233

378

37

94

Tabel 5 viser sammenhængen mellem køn og tilfredshed med udbyttet af dagens biblioteksbesøg. På det overordnede niveau, hvor alle de humaniorastuderende undersøges under et, kan vi ikke konstatere nogen forskel i tilfredshed - eller i hvert fald ikke en statistisk signifikant forskel. Der synes dog at være en meget svag tendens til, at kvinder udtrykker en lidt større grad af tilfredshed med biblioteksbesøget 
end mandlige studerende. Dette forhold er analyseret i forhold til hver af de 6 studiegrupper, og det er kun blandt de litteraturstuderende, at vi med sikkerhed kan udtale os om, at de kvindelige studerende er mere tilfredse end de mandlige studerende. Dette forhold fremgår også af tabel 5 . I forhold til de øvrige 5 grupper er der ingen signifikant forskel.

Det samme forhold, nemlig sammenhængen mellem køn og udbytte, er ligeledes analyseret i forhold til de tre betjeningssteder. Det viser sig, at der ved Amagerinstitutionen og ved Slotsholmen ikke er nogen forskel i tilfredshed med udbyttet blandt mandlige og kvindelige studerende, hvorimod en sådan statistisk signifikant forskel findes ved biblioteket i Fiolstræde, hvor de kvindelige studerende er langt mere tilfredse med udbyttet end de mandlige studerende.

\section{Litteraturefterspørgsel og succes}

I forskningsrapporten blev der gjort forholdvis meget ud af at undersøge de studerendes efterspørgel efter litteratur og deres succes med dette. Det blev undersøgt, hvor mange der kom med titelforespørgsler, og hvor mange der kom efter litteratur om emner.

Tabel 6: Tabel over udvalgte fags studerende og deres succes mht titel- og emneefterspørgsler; i \%

\begin{tabular}{lccccccc} 
& \multicolumn{3}{l}{ Hvor mange titler? } & \multicolumn{3}{l}{ Litt om emne? } \\
& alle & nogle & ingen & total & Ja & Nej & total \\
hum & 21 & 64 & 15 & 39 & 74 & 26 & 58 \\
medier, kunst & 28 & 53 & 20 & 40 & 74 & 26 & 50 \\
litteratur & 24 & 54 & 23 & 80 & 65 & 35 & 81 \\
sprog & 28 & 38 & 33 & 60 & 63 & 37 & 90 \\
kultur, filosofi & 25 & 55 & 20 & 65 & 71 & 29 & 78 \\
historie & 29 & 54 & 17 & 59 & 73 & 27 & 78 \\
total & 88 & 180 & 75 & 343 & 30 & 133 & 435 \\
& chi i anden $=9,6$ & $\mathrm{p}=0,47$ & & & chi i anden $=3,8$ & $\mathrm{p}=0,57$
\end{tabular}

Det fremgår ganske tydeligt, at der ingen sammenhæng er mellem de emner og fag, der studeres og sandsynligheden for at få den litteratur, man kommer efter. Det er bemærkelsesværdigt, hvor ens forholdene er for de enkelte grupper af studerende. Tabel 6 viser de tre betjeningssteder under ét.

Overordnet kan det fremhæves, at der heller ikke på nogle af de tre betjeningssteder synes at være en sammenhæng mellem succes og studieretning, emne eller fag. Der kan dog peges på enkelte tendenser, der er interessante. Fortolkningen må 
dog tage hensyn til, at brugergrupperne er begrænsede, idet konklusionerne blot drages på basis af de 6 emner og fag.

Ved Amagerafdelingen får $19 \%$ af brugerne alle de titler, de kommer efter. $53 \%$ får nogle og $28 \%$ får ingen. Det er især de sprogstuderende, der adskiller sig, idet over 40 \% af disse ikke får nogle af de ønskede titler. 64 \% får litteratur om emner. Det er igen de sprogstuderende, der er de mest uheldige, idet kun 59 \% făr ønsket litteratur om emner.

Ved Slotsholmen er billedet sådan, at $36 \%$ af brugerne får de titler de kommer efter. 51 \% får nogle og kun $13 \%$ får ingen. Her er det især de litteraturstuderende, der går forgæves, idet $31 \%$ af disse ikke får nogle af de titler de kommer efter. Hele $81 \%$ får anvendelig litteratur om emner. Der er ingen markante forskelle mellem de 6 grupper af studerende.

Forholdene vedrørende titler ser meget broget ud ved Fiolstræde. 30 \% får alle titler. $44 \%$ får nogle og $16 \%$ får ingen. Der er store forskelle mellem de enkelte grupper, der dog ikke tilsammen tæller mere end 57 personer, hvorfor der er stor statistisk usikkerhed, hvilket gør det vanskeligt at udtale sig om, at der er forskelle mellem de enkelte grupper. $73 \%$ får litteratur om emner. De litteraturstuderende synes kun at være heldige i $58 \%$ af tilfældene. Ellers er der kun små udsving mellem grupperne af studerende.

\section{Vurderinger af dokumentforsyning}

De studerende er ligeledes blevet bedt om at vurdere betjeningsstedernes sammensætning af materialer i forhold til de studerendes behov for litteratur til studierne. $64 \%, 27 \%$ og $9 \%$ vurderer samlingerne som helhed tilfredsstillende, nogenlunde eller utilfredsstillende. Der er ingen forskelle i vurderingen blandt de enkelte grupper af studerende, omend der synes at være en svag tendens til, at især historiestuderende er positive, idet hele $72 \%$ af disse finder samlingerne tilfredsstillende. $14 \%$ af de studerende, der læser Medier, kunst eller musik finder samlingerne utilfredsstillende. Det er brugergruppen ved Amagerafdelingen, der har den mindst positive vurdering af samlingen, men der er ikke tale om de store forskelle mellem de tre betjeningssteders brugergrupper. Der synes iøvrigt heller ikke at være forskel i vurderingen af kvaliteten af samlinger, der hænger sammen med de studerendes køn. Det er indlysende, at netop spørgsmålet om de studerendes vurdering af et biblioteks materialebestand er meget vanskeligt at fortolke. Det er uklart, i hvilken 
udstrækning den enkelte studerende vurderer Det kongelige Bibliotek som en enhed med forskellige betjeningssteder, der så at sige trækker på samme lager eller i hvilken udstrækning svarene har udgangspunkt $i$, at det enkelte betjeningssted betragtes som en næsten selvstændig forsyningsenhed.

Det er derfor mere interessant at se nøjere på, i hvilken udstrækning de studerende oplever, at de har vanskeligheder ved at få den litteratur, de har behov for.

Tabel 7: Har du tit vanskeligt ved at få den relevante litteratur; i \%

hum

medier, kunst

litteratur

sprog

kultur, filosofi

historie

lalt

chi $i$ anden $=31,9 p=0,0004$

$\begin{array}{cccc}\text { ofte } & \text { af og til } & \text { sjældent } & \text { ialt } \\ 18 & 53 & 30 & 74 \\ 13 & 72 & 15 & 61 \\ 31 & 48 & 21 & 131 \\ 13 & 59 & 28 & 118 \\ 11 & 64 & 26 & 105 \\ 14 & 57 & 30 & 118 \\ 104 & 350 & 153 & 607\end{array}$

Hvis vi ser på materialet som helhed, er det tydeligt, at der er en stor forskel på de 6 grupper af studerende. Det er især gruppen af litteraturstuderende, der for næsten en tredjedels vedkommende angiver, at de ofte har besvær med at få fat i den nødvendige litteratur. Denne gruppe adskiller sig markant fra de øvrige 5 grupper, hvor forskellene synes at være forholdsvis små. Amagerbiblioteket har i denne delundersøgelse hovedparten af de studerende som brugere, hvorfor det kan være interessant at se på, hvorledes det samme spørgsmål er besvaret af brugergruppen der. Det fremgår af tabel 8.

Tabel 8: Har du tit vanskeligt ved at få den relevante litteratur. Amagerafdelingen; i \%

$\begin{array}{lcccc} & \text { ofte } & \text { af og til } & \text { sjældent } & \text { ialt } \\ \text { hum } & 17 & 58 & 25 & 36 \\ \text { medier, kunst } & 15 & 74 & 12 & 34 \\ \text { litteratur } & 34 & 50 & 16 & 99 \\ \text { sprog } & 16 & 56 & 28 & 87 \\ \text { kultur, filosofi } & 15 & 68 & 17 & 47 \\ \text { historie } & 11 & 64 & 25 & 54 \\ \text { lalt } & 72 & 210 & 74 & 356\end{array}$

chi $i$ anden $=22,9 p=0,01$

De tendenser vi så i materialet som helhed forstærkes, når vi blot ser på Amagerafdelingen. Hele $34 \%$ af de litteraturstuderende angiver, at de ofte har vanskelig- 
hed ved at få litteratur. Der er ingen tvivl om, at de forskellige grupper af studerende har meget divergerende oplevelser af, hvorledes deres forsyningssituation med hensyn til litteratur er. Det er iøvrigt ikke uinteressant at notere, at samme undersøgelse i forhold til Slotsholmen og Fiolstræde viser, at der blandt disse to brugergrupper ikke er nogen forskel i opfattelsen af det her behandlede spørgsmål.

En anden ikke uinteressant variant i forhold til materialet som helhed er, at der er en meget markant forskel i vurderingen af dette spørgsmål i forhold til de studerendes køn. Gruppen af mandlige studerende udviser nemlig ingen forskel i vurderingen, hvorimod der er meget store forskelle i de kvindelige studerendes vurdering.

Det er indlysende, at opfattelsen af vanskeligheden ved at få litteratur kan have indflydelse på, hvorledes man reagerer i forskellige situationer. En indikator på næsten samme forhold er, i hvilken udstrækning studerende undlader at foretage en reservation eller bestilling af et dokument, der ikke umiddelbart er til stede i samlingen. Spørgsmålet indeholder naturligvis mange aspekter. Der er først og fremmest tale om, at de studerende vurderer sandsynligheden for at få dokumentet til tiden. Vurderingen af denne sandsynlighed vil afhænge af kødannelsen - antal reservationer på dokumentet, tidligere erfaringer med reservationer, informationsbehovets tyngde o.lign. Der er dog stadigvæk tale om en indikator på et ikke-opfyldt informationsbehov.

Tabel 9: Undlader du ofte at reservere materialer, fordi de er udlånte? i \%

hum

medier, kunst

litteratur

sprog

kultur, filosofi

historie

lalt

chi $i$ anden $=21,5 p=0,018$

$\begin{array}{cccc}\text { meget ofte } & \text { ofte } & \text { sjældent } & \text { ialt } \\ 18 & 39 & 43 & 72 \\ 9 & 43 & 48 & 58 \\ 27 & 39 & 36 & 130 \\ 8 & 40 & 51 & 119 \\ 13 & 37 & 50 & 106 \\ 10 & 40 & 50 & 115 \\ 85 & 237 & 278 & 600\end{array}$

Det er over halvdelen af de humaniorastuderende, der angiver, at de ofte eller meget ofte undlader at reservere et dokument, fordi det er udlånt. Der er statistisk signifikant forskel på de forskellige grupper af studerende, idet de litteraturstuderende angiver for $64 \%$ s vedkommende, at de hyppigt undlader reservation. Dette resultat er i overensstemmelse med det foregående resultat vedrørende vurderingen af van- 
skeligheden ved at få den for studiet relevante litteratur. Der er kun ringe forskel blandt de øvrige 5 grupper af studerende.

Denne forskel skyldes igen forholdene ved Amager. Der er ingen forskel mellem de to øvrige betjeningsteders brugergrupper. Og der er i forhold til materialet som helhed heller ingen forskel blandt de mandlige studerende, hvorimod det er tilfældet blandt de kvindelige studerende.

Uden at der skal drages for drastiske konklusioner, synes der at tegne sig et billede af, at kvindelige litteraturstuderende på en række områder adskiller sig fra øvrige studerende, når bibliotekernes muligheder for at tilfredsstille informationsbehov vurderes.

Det sidste forhold, som vedrører de humaniorastuderendes opfattelse af Det kongelige Biblioteks service, drejer sig om, hvorledes de studerende generelt vurderer ventetiden på litteratur, de bestiller. Det er vigtigt at understrege, at der er tale om opfattelser. Spørgsmålet knytter sig ikke til en konkret lånetransaktion, men netop om opfattelser. Disse opfattelser kan have mange kilder.

Tabel 10: Hvordan synes du, at ventetiden generelt er på bestilt litteratur? i \%

$\begin{array}{lcccc} & \text { lang } & \text { rimelig } & \text { kort } & \text { ialt } \\ \text { hum } & 17 & 58 & 25 & 71 \\ \text { medier, kunst } & 21 & 45 & 34 & 62 \\ \text { litteratur } & 9 & 55 & 36 & 131 \\ \text { sprog } & 21 & 63 & 16 & 117 \\ \text { kultur, filosofi } & 29 & 54 & 17 & 105 \\ \text { historie } & 28 & 54 & 18 & 115 \\ \text { lalt } & 123 & 334 & 144 & 601\end{array}$

chi $i$ anden $=34,5 p=0,00015$

Der kan være tale om tidligere erfaringer. Der kan være tale om, at opfattelsen er influeret af studiemiljøets almindelige samtaler om biblioteker og biblioteksservice. Der eksisterer også andre muligheder. Det er naturligvis betryggende, at over halvdelen af de studerende finder ventetiden rimelig. Men over $20 \%$ finder altså ventetiden værende lang. Vi registrerer igen, at der er en markant forskel mellem studiegrupperne, idet de litteraturstuderende er den gruppe, der har den mest positive holdning til ventetiden på bestilt litteratur. Dette resultat står faktisk i skærende modstrid til de resultater, der er præsenteret ovenfor. De her foretagne analyser kan ikke forklare dette forhold, men der er i materialet muligheder for at analysere dybere. 
Det er iøvrigt igen blot ved Amagerafdelingen, at der tegner sig en forskel i de studerendes opfattelse.

I den bagvedliggende rapport ${ }^{1}$ så vi, at de studerendes opfattelse af ventetiden på den litteratur, de kom for at hente efter at en bestilling var effektueret, var langt mere positiv end den generelle holdning til ventetid. Det vil derfor ikke være urimeligt at antage, at den generelle holdning til ventetid er afhængig af studietrin og biblioteksbenyttelseshyppighed. Det undersøges kort i det følgende.

Statistiske analyser af disse forhold viser, at der ingen sammenhæng er mellem opfattelsen af ventetid på litteratur og biblioteksbenyttelseshyppighed samt studietrin.

\section{De humaniorastuderende og edb}

Det sidste spørgsmål vi skal se på i denne artikel er de studerendes forhold til edbkatalogen.

Knap $57 \%$ af de studerende fra de 6 studiegrupper har anvendt edb-katalogen under dagens biblioteksbesøg. Der er kun meget små udsving mellem de enkelte grupper, hvorfor der må konkluderes, at der ikke er forskel i benyttelsesintensitet af edb-katalogen afhængig af det fag eller emne, der læses.

Der er heller ingen forskel i benyttelse af edb blandt de studerende afhængigt af det betjeningssted, der anvendes i forbindelse med dagens besøg.

Der er heller ingen forskel i den måde, studerende fra forskellige fag søger på. Cirka halvdelen af de studerende angiver, at de både har foretaget en titelsøgning og en emnesøgning. Det synes især at være de historiestuderende, der søger på denne måde, idet $63 \%$ af dem angiver, at de har foretaget begge søgninger. Men forskellen er altså ikke statistisk signifikant.

$30 \%$ af de studerende synes, at det er vanskeligt at foretage søgninger i edbkatalogen. Godt $35 \%$ finder, at det går nogenlunde, og endelig er der knap $35 \%$ der finder det let. Der er ingen forskel i opfattelsen af sværhedsgrad afhængig af det fag og emne, de studerende læser.

De studerende er også blevet bedt om at angive, hvorledes de vurderer udbyttet af deres edb-søgning. $70 \%$ finder søgeudbyttet tilfredsstillende. $23 \%$ finder det nogenlunde. $7 \%$ finder det utilfredsstillende. Heller ikke her kan der overhovedet registreres nogle forskelle mellem studerende fra de 6 grupper af fag.

I forhold til anvendelsen af edb-katalogen som et redskab i litteratursøgning er 
det interessant, at der ikke kan konstateres forskelle mellem de studerende fra forskellige grupper af fag. Fordelingsmønsteret på de enkelte variabler er meget ensartet, og det synes givet, at de humaniorastuderendes anvendelse af og vurdering af edb-katalogen ikke afhænger af fag.

Der er enkelte forhold, hvor der kan konstateres visse forskelle. I REX er det muligt at få en lang række informationer, der er af ikke-bibliografisk karakter. Kun godt $10 \%$ af de studerende har søgt disse informationer. Med hensyn til denne variabel kan der dog konstateres forskelle blandt de studerende, idet grupperne af studerende der læser sprog, litteratur samt medier, kunst og musik er langt mindre tilbøjelige til at anvende denne del af informationssystemet, der anvendes noget mere intensivt af studerende, der læser historie, filosofi etc.

Tabel 11 viser, at de studerende har en klar fornemmelse af, at de i meget stor udstrækning, herunder også hyppigt, har behov for at kunne søge litteratur i edbkatalogen.

Tabel II: Behov for at kunne foretage edb-søgninger; i \%

$\begin{array}{lcccc} & \text { ofte } & \text { af og til } & \text { næsten aldrig } & \text { ialt } \\ \text { hum } & 69 & 27 & 4 & 73 \\ \text { medier, kunst } & 47 & 46 & 7 & 68 \\ \text { litteratur } & 62 & 31 & 8 & 134 \\ \text { sprog } & 56 & 33 & 12 & 120 \\ \text { kultur, filosofi } & 66 & 26 & 8 & 107 \\ \text { historie } & 72 & 22 & 6 & 118 \\ \text { lalt } & 388 & 185 & 47 & 620\end{array}$

chi $i$ anden $=19 p=0,04$

Der er dog forskel på angivelsen af behovet blandt de forskellige grupper af studerende. Det er de studerende, der læser medier, kunst og musik der angiver et mindre behov for ofte at søge litteratur. Også de sprogstuderende angiver et mindre behov for at foretage søgninger i edb-katalogen. Historiestuderende synes at være en gruppe, hvor behovet føles størst. Forskellene er så store, at det kan konkluderes, at de forskellige grupper af studerende har forskellig opfattelse af behovet. Men under alle omstændigheder er behovet på et højt niveau. Forskellene kan skyldes forskelle i de måder studielitteraturen er skruet sammen på i de forskellige studier. Hermed er der ligeledes indirekte peget på studietrinet som en faktor, der kan have indflydelse. Hvis de studerende deles op i studerende på henholdsvis 1. til 3. studietrin i en gruppe og en anden i en gruppe bestående af 4. - 6. studietrin, kan vi 
indenfor hver af disse grupper undersøge sammenhængen mellem behov og fag.

Her kommer der interessante resultater frem. Ældre studerende angiver for over $70 \%$ s vedkommende, at de ofte har behov for at kunne foretage edb-søgninger mod de yngre studerendes 55\%. Der er altså tale om en meget markant forskel, der tydeligt viser, at jo længere fremme man er i studiet, des større er behovet for at kunne foretage søgninger i edb-katalogen.

Det næste vi ser på, er gruppen af studerende på de tre første studietrin. Her må vi konstatere, at der er store forskelle i behovet for at kunne foretage edb-søgninger. Studerende indenfor gruppen medier, kunst og musik angiver kun for $31 \%$ s vedkommende behov for ofte at kunne. $38 \%$ af de sprogstuderende angiver behovet ofte og $17 \%$ af disse angiver, at de næsten aldrig har behov for at kunne foretage søgninger i REX. Historiestuderende angiver behovet ofte i $67 \%$ af tilfældene.

Helt anderledes ser billedet ud for de ældre studerende. $70 \%$ af de ældre studerende angiver, at de ofte har behov for at kunne foretage en edb-søgning. Der er ingen statistisk signifikant forskel på studerende fra de forskellige fag. Eksempelvis angiver $65 \%$ af de sprogstuderende at de ofte har behov.

Vi kan altså konstatere, at forskellen mellem de studerende mht angivelse af behov for at kunne foretage edb-søgning primært stammer fra de yngre studerende, hvor enkelte fag ikke synes at have samme behov som andre. Derimod er der ikke forskel på ældre studerende uanset det fag, de studerer.

Det sidste spørgsmål vi analyserer i denne sammenhæng er, i hvilken udstrækning de studerende angiver, at de oplever generende ventetid ved edb-terminalerne.

I tabel 12 vises svarerne fra de historiestuderende. Det fremgår, at problemerne opleves som størst ved Amagerafdelingen. Dette er et eksempel på det generelle mønster, nemlig at alle de humaniorastuderende oplever problemet størst her og mindst ved Fiolstræde.

Tabel I2: Hvor hyppigt opleves generende ventetider ved edb-terminalerne. Historiestuderende; $\mathrm{i} \%$

$\begin{array}{lccccr} & \text { meget ofte } & \text { ofte } & \text { af og til } & \text { næsten aldrig } & \text { ialt } \\ \text { Amager } & 16 & 27 & 33 & 25 & 49 \\ \text { Slotsholmen } & 9 & 26 & 35 & 30 & 43 \\ \text { Fiolstræde } & 13 & 20 & 27 & 40 & 15 \\ \text { lalt } & 14 & 27 & 35 & 31 & 107\end{array}$

Der er forskel på de studerendes vurdering af ventetiden ved de tre betjeningssteder. Når man herefter analyserer det enkelte betjeningssted i forhold til de fag og 
emner, de studerende læser, må der konkluderes, at ventetiden i forhold til det enkelte betjeningssted opleves meget ens af de studerende - uanset det fag de læser. Det samme er iøvrigt tilfældet med studietrin. Her vurderes betjeningsstederne på samme måde.

\section{Konklusion}

Der er grænser for, hvor epokegørende konklusioner der kan drages på basis af denne lille artikel. Artiklen var først og fremmest et forsøg på at analysere udvalgte studentergrupper mere dybtgående end det er sket i den omtalte forskningsrapport. Det viser sig også, at der i en række sammenhænge kommer mere differentierede resultater ud af analyserne. På trods af tilsyneladende ligheder er der forskelle i oplevelsen af litteraturforsyningen blandt de forskelle grupper af humaniorastuderende. Der synes ligeledes at være forskelle mellem nogle af de mandlige og nogle af de kvindelige studerende. Et andet interessant resultat af mere metodisk karakter er, at forskellen mellem yngre og ældre studerende mht deres behov for edb-søgninger er så stort. Der er ingen forskel i dette behov blandt de ældre studerende, hvorimod behovet varierer virkelig meget mellem de forskellige grupper af yngre studerende. Hvis der ikke foretages denne type mere differentierede analyser, er der oplagte muligheder for at drage både forkerte og forhastede beslutninger.

Denne lille artikel vil være den første af flere, der analyserer videre på det forholdsvis omfattende materiale.

0 Pors, Niels Ole: Studerende og Biblioteker: En undersogelse af studerrendes biblioteksbenyttelse. Kbh. Skrifter fra Statens Bibliotekstjeneste. 1995.
Pors, Niels Ole: Studenter og Biblioteker: En undersogelse af studerendes benyttelse af $K_{0}$ benhavns Kommunes Biblioteker, Det Kongelige Bibliotek og Handelshøjskolens Bibliotek. Rapport. Februar 1995. 204 s. 